\title{
Zalecenia PTFM dotyczące prowadzenia kontroli ułożenia pacjentów leczonych wiązkami zewnętrznymi. Część I - Wstęp
}

\author{
Tomasz Piotrowski ${ }^{1,2, a}$ \\ ${ }^{l}$ Katedra i Zakład Elektroradiologii, Uniwersytet Medyczny w Poznaniu \\ ${ }^{2}$ Zakład Fizyki Medycznej, Wielkopolskie Centrum Onkologii, Poznań \\ ${ }^{a}$ E-mail address: tomasz.piotrowski@wco.pl
}

\section{Słowem wstępu}

Jednym z kluczowych elementów decydujących o powodzeniu leczenia promieniowaniem jonizującym jest podanie dawki terapeutycznej w ściśle określony blok tkanek, którego granice wyznaczają obszar napromieniania. W przypadku nieskomplikowanych technik radioterapeutycznych jest to możliwe poprzez staranną kontrolę parametrów określających zależności geometryczne pomiędzy aparatem a powierzchnią ciała pacjenta, wykonaną przy użyciu skali telemetrycznej, symulacji świetlnej pola terapeutycznego czy też systemu laserów. Niemniej jednak zaawansowane techniki radioterapeutyczne takie jak trójwymiarowa radioterapia konformalna (3DCRT) czy też radioterapia $\mathrm{z}$ modulowanym natężeniem wiązek terapeutycznych (IMRT, VMAT) prowadzą do wzrostu konformalności rozkładu dawki w ciele pacjenta i tym samym obarczone są większym prawdopodobieństwem popełnienia błędu geometrycznego, którego skutkiem może być podanie niepełnej dawki terapeutycznej do obszaru napromieniania.

W przypadku technik 3DCRT czy też technik IMRT, VMAT, w celu uniknięcia błędu geometrycznego konieczna jest weryfikacja obrazowa. Weryfikacja obrazowa umożliwia ocenę zgodności obszaru aktualnie napromienianego na aparacie terapeutycznym z obszarem, który został wyznaczony w trakcie planowania leczenia. Współczesne akceleratory medyczne wyposażone są w urządzenia do obrazowania, dzięki którym możliwe jest uzyskanie dwuwymiarowych zdjęć topograficznych lub zestawu obrazów tomograficznych.

Weryfikacja obrazowa, nie powinna być przeprowadzana $\mathrm{w}$ sposób chaotyczny czy też losowy. W celu efektywnego wykorzystania informacji powstałych w wyniku porównan, należy usystematyzować procedurę oceny zgodności tworząc swój własny protokół bądź też wykorzystując jeden $\mathrm{z}$ opracowanych protokołów oceny zgodności [1-4].

Celem niniejszego opracowania jest usystematyzowanie wiedzy dotyczącej metod weryfikacji obrazowej oraz przedstawienie podstawowych wytycznych, jak takowa powinna być przeprowadzana $\mathrm{w}$ ośrodkach terapeutycznych stosujących promieniowanie jonizujące w Polsce.

Gorąco polecam,

dr hab. n. med. Tomasz Piotrowski

\section{Literatura}

[1] The Royal College of Radiologists, Society and College of Radiographers, Institute of Physics and Engineering in Medicine. On Target: Ensuring Geometric Accuracy in Radiotherapy. The Royal College of Radiologists. London, 2008.

[2] Piziorska M, Kukołowicz P, Zawadzka A, et al. Adaptive off-line protocol for prostate external radiotherapy with cone beam computer tomography. Strahlenther Onkol. 2012;188(11):1003-1009.

[3] Adamczyk M, Piotrowski T, Adamiak E. Evaluation of combining bony anatomy and soft tissue position correction strategies for IMRT prostate cancer patients. Rep Pract Oncol Radiother. 2012;17(2):104-109.

[4] Piotrowski T, Kaczmarek K, Bajon T, et al. Evaluation of image-guidance strategies for prostate cancer. Technol Cancer Res Treat. 2014;13(6):583-591. 